\title{
The International and
}

\section{Comparative Law Quarterly}

VOLUME 13

1964

William S. Hein \& Co., Inc.

Buffalo, New York

2003 
(1) British Institute of International and Comparative Law 1964.

Published by Oxford University Press.

All rights reserved

This book has been digitally archived, to maintain the quality of the original work for future generations of legal researchers, by William S. Hein \& Co., Inc.

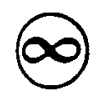

This volume is printed on acid-free paper by William S. Hein \& Co., Inc. 


\title{
The British Institute of International and Comparative Law
}

\author{
Chairman of the Council of Management \\ The Rt. Hon. Lord Denning
}

\begin{abstract}
Chairmen of Sections of the Advisory Board
Public International Law

The RT. Hon.

Lord Shawcross, Q.c.

Private International Law

THE HoN.

Mr. Justice Scarman
\end{abstract}

\author{
Comparative Law \\ (includhig Commonwealth, Colonial and Foreign Law) \\ The Rt. Hon. Lord Justice Diplock
}

Director: Norman S. Margh

Contribution to the International and Comparative Law Quarterly oxpress the viows of their authors and not nocessarily the viows of the Editorial Board or of the British Instiftets of International and Comparatios Law. 


\title{
EDITORIAL BOARD
}

\author{
General Editor
}

Norkan S. Margh

\section{Assistant General Editor \\ Elizabeth EvatT}

\author{
Editors \\ Public International Lar \\ D. H. N. Johsson \\ Private International Laro \\ P. B. Cartrer
}

Comparative Law

A. K. R. Kiralfy

(C) 1964

British Institute of International and Comparative Law 


\title{
TABLE OF CONTENTS
}

\author{
Articles and Notes
}

(An alphabetical Index of contributors, together with the Index of Cases, Index of Books and Subject Index is to be found at the end of this Volume (p. 1527 et seq.))

\section{ARTICLES}

Charles de Visscher, Kenneth Carpmael and C. John Colombos: Sir Cecil Hurst: Two Tributes . . 1

Donald von Landauer: Matrimonial Caubes in French Law P. E. Nygh: Foneign Status, Public Policy and DibcreTION .

J. L. R. Davis: Conditional Saleg and Chattel Mortoageg IN THE Confuict of Law

Charles Henry Alexandrowicz: Intennational Law in the Municipal Sphene according to Aubtralian DecigIONB • • • • • • •

Robert W. Gregg: The United Natrons and the OPTum

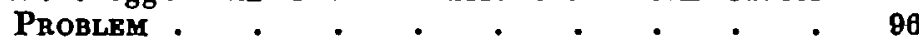

J. N. Saxena: India-THe Extradition ACT, 1962 . 116

L. Neville Brown: Family Maintenance and it8 EnforceMENT $\mathrm{nN}$ THE UNITED STATES. . . . .

Anthony John Boyle: The Sale of Controulung Shares: american Law and the Jenking Commitiee .

Bernatd Brown: The "Ordinary Man" in Provocation: Anglo-Saxon AtTtTudes and "UnRzabonable NonENGLIgHMEN". . . . . . .

Norman Bentwich: The Legal Sy8tem of Israet . . $\quad$ - 286

$R$. $Y$. Jennings : Recent Developmente nN THE INTERnational Law Commigsion: Its Relation to The Sources of International Law.

Katol N. Ge88: Permanent Sovereignty over Naturat Regources: An Analytical Review of the United Nationg Decharation and Itg Genesis

D. R. Anderson: Regervations to Multulateral ConvenTIONB: A Re-Examination . . . . . 450

J. Unget: Life Insurance and tere Conflict of Laws . $\quad 482$

J. P. W. B. Mcauslan: The Republican Constitution of TANGaNyika

W. C. Ekow Daniels: The Intsanction of Enalish Law with Customary Law in Wegt Africa. • . .

V. G. Ventutini: Monopolies and Restrictive Trade Prac-

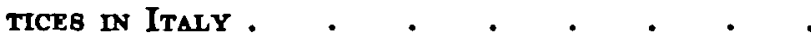

Sir Guy Powles: The Crimen's Righto aganngt the Modern State, and its Regponbibmitres to Him . . . 
E. Sabbath: Erfects of Mirtakeg in Contract8: A Study in Comparative law . . . . .

Dennis Thompson: THe EURopean Economic Community: Internal Defelopmenta since the Breakdown of the British Negotiations . . . . .

K. $R$. Simmonds: The UN Asgegsments Advisory Opinion Richard B. Lillich: The Jurisprudence of the Foreign Compensation Commisbion: Eutgible Claimanta. .

H. H. Almond, Jr. : The Anglo-Japanege Commercial Treaty OP 1968 . . . . . . . . .

F. B. Schick: Problems of a Space Law in the United Nations . . . . . . . . . .

Jean-Flavien Lalive: Contracts Between a State or a Statr Agency and a Foreign Company-Theory and Practice: Choice of law in a New arbitration CABR.

G. W. Bartholomezo: Recognition of Polygamous MarkiAGES IN AMERICa . . . . . . .

D. H. N. Johngon: Thr Case concerning the Northern

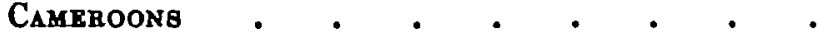

H. F. van Panhuys: IN the Borderland between the ACT of State Doctrine and Quebtrons of JuRigdic-

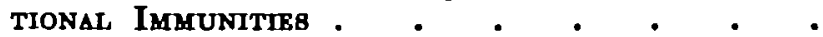

G. E. do Nascimento e Silva: The Vienna Confrerenck on Consular Retations . . . . . .

John W. Bridge: The Cage for an International Count of Crminal Justice and the formulation of International Criminal Law . . . . .

Roland Drago: Some Recent Reforms of the French ConBEIL D'ETAT

Charles J. Haughey: Law Refora in Ireland . . .

Hilary Cartwright: The Law of Obluoations in England and Germany: Some Comparative Reflections in the Light of the Proposals dn " Law Reform Now"

L. A. Sheridan: Conbttrutional Problems of Malaygia • Lalith W. Athulathmudali: ThE LAW of Defamation IN Ceylon-A Study in the Inter-action of Enough and Roman-Dutch Law.

H. H. Marshall: Statute Law Revision in the CommonWEALTH

\section{NOTES}

The Second Protocol to the European Convention of Human Rights, Ralph Beddard

The Crisis in International Law and the Law of Sociality, Giorgio Del Vecchio . . . . . . .

The Hearings Regulation of the E.E.C. Commission, Dennis Thompson 
Quebec (Provincial) and Canadian (Federal) Rules on International Procedure (Internationa] Judicial Assistance) in Civil and Commercial Matters, $L$. Kos-Rabceivecg Zubkowski . . . . . Interpretation of the Constitution of Western Nigeria : A Privy Council Decision, H. H. Marshall . . .

Jewish Law in Southern Asia, J. Duncan M. Derrett . . 288

Fifth International Congress for Labour Law and Social Legislation, September 1968, O. Kahn-Freund .

The International Court of Justice: Sir Percy Spender; Sir V. K. Wellington Koo . . . . . .

International Inspection in Pelagic Whaling, Erwin $C$. Surrency. . . . A Code of International Trade, Alfred Drucker . . .

Council of Europe: (1) The Legal Programme of the Council of Europe, K. R. Simmonds . . . . .

Council of Europe: (2) The European Convention of Human Rights, Norman S. Mars'h.

801

665

666

Council of Europe: (8) Convention on the Unification of Certain Points of Substantive Law on Patents for Inventions, Dennis Thompson . . . . .

The Wills Act, 1868, J. H. C. Morris . . . . .

A Recent Contribution to the Problem of Torts in the Conflict of Laws, S. Strömholm.

The Judicial Committee of the Privy Council: A Waning Jurisdiction, H. H. Marshall . • . . $\quad 697$

The European Social Charter, D. J. Harris . . . . 1076

The Polish Merchant Shipping Code, D. Lasok . 1087

The Principle of Acknowledgment-or Recognition of Paternity under Customary Law in Nigeria, A. B. Kasunmu.

The Duration of International Jurisdictional Immunities (Based on Zoernsch v. Waldock and another), K. R. Simmonds .

State Succession to Treaties in the Commonwealth: Two Replies, K. J. Keith and D.P. O'Connell . . .

The Dispute Between France and Brazil over Lobster Fishing in the Atlantic, Issam Azzam . . . . .

Anglo-American Conflict of International Jurisdiction, F. A. Mann •. . . . . .

Foreign Arbitral Awards and Foreign Judgments based upon such Awards, V. C. Govindaraj .

1088

$148 B$

1441

1458

1460 1465

Article 85 of the Rome Treaty-A Matter of Translation, E. J. Cohn . . . . . . . .

The Duty to Conclude a Contract in East European Law, Stephen Szaszy . . . . . . . . . 1470

The Israel Defamation Bill 1963, Ernst Livneh . . . 1482

Certiorari and Error Apparent on the Face of the Record in Indian Law, H. M. Seervai 


\title{
The International and Comparative Law Quarterly
}

(incorporating the Quarterly of the Society of Comparative Legislation and International Law and the Transactions of the Grotius Society).

\author{
General Editor \\ Norman S. Marsh \\ Assistant General Editor \\ Euizabetr Evatt
}
Editors
Public International Law
Private International Law
D. H. N. JoBnson
P. B. Carter

Comparative Law

A. K. R. KiRaLFY

Editorial Communications

All correspondence Including books for replex and buslness oommunlcations, as well as contributions [rhloh should be typed], should be addressed as follows:

\author{
The General Editor, \\ International and Comparatire Laz Quarterly, \\ British Institute of International and Comparatire Lar, \\ 1 Temple Gardens, London, E.C.4.
}

Contributions to the International and Comparative Law Quarterly oxpress the virws of their authors and not necessarily the viows of the Editorial Board or of the British Institute of International and Comparative Law.

I.C.LQ.

front 


\section{THE INTERNATIONAL AND COMPARATIVE LAW QUARTERLY}

\begin{tabular}{lll}
\hline Volume 18 & Part 1 & .Tanuary 1964 \\
\hline
\end{tabular}

\section{ARTICLES}

Charles de Visscher,

Kenneth Carpmael and C. John Colombos.

Sir Cecil Hurgt: Two Tributes . 1

Donald von Landauet Mathimonial Cauges in French Law 6

P. E. Nygh - . Foreign Status, Public Pulicy and Discretion . $. \quad \cdot \quad . \quad 80$

J. L. R. Davis - - Conditional Saleg and Chattel Mortagerb in the Conflict of Laws • . . . . . $\quad 58$

Charles Henty Alexan- International Law in the Municipal drowicz . . . SpHERe according to Aubtralian DECISIONS . . . . . $\quad$. 78

Robert W. Gregg - The United Nations and the Opium Problem • • • • $\cdot 96$

J. N. Saxena - . India-the Extradition Act, 1962 - 116

L. Neville Broven - Famly Maintenance and its ENFORCEMENT IN THE UNITED STATES 139

Anthony John Boyle The Sale of Controluing Shares: AMerican Law and the Jenkins ConMITTEE . $. \quad . \quad . \quad . \quad 185$

Betnatd Broten . . The "Ordinary man" in Provocarion: Anglo-Saxon Attitudeg AND "UNREABONABLE NONEnglibhmen". . . . 203

Norman Bentwich . The Legal System of Israel . - 230

\section{NOTES}

The Second Protocol to the European Convention of Human Rights, Ralph Beddard. • • • . . The Crisis in International Law and the Law of Sociality,

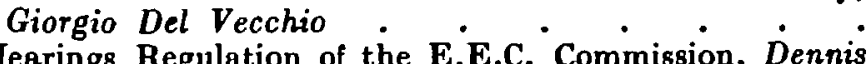

The Hearings Regulation of the E.E.C. Commission, Dennis

Thompson 
Quebec (Provincial) and Canadian (Federal) Rules on International Procedure (International Judicial Assistance)

in Civil and Commercial Matters, L. Kos-Rabcerwicz

Zubkoreski

Interpretation of the Constitution of Western Nigeria : a Privy

Council Decision, H. H. Marshall . . . . . 280

Judge Made Law in the Colonies, R. W. Cannon . . - 284

Jewish Law in Southern Asia, J. Duncan M. Derrett . . 288

Fifth International Congress for Labour Law and Social Legislation, September 1069, O. Kahn-Freund . . .

\section{BOOK REYIEWS}

Les Difficultes financières des Nations Unies et les obligations des Etats membres. Chronique de Politique Etrangère. Volume XVI, No. 1-2, 1963. (K. R. Simmonds) . Robert B. Eluert, NATO "Fair Trial" Saleguards (J. E. S. Fawcett)

Carsten Smtth, The Relation Betroeen Proceedings and Pre-

mises (N. Maryan Green) A. A. Fatouros, Government Guarantees tc Foreign Investors
A.

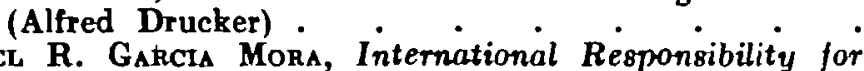
Manued R. Garcts Mora, International Responsibility for
Hostile Acts of Private Persons against Foreign States (D. W. Greig) . . . • • • . .

Gamal el din AtTIA, Les Forces Armées des Nations Unies en Corée et au Moyen-Orient (Gillian White) . .

Shrgenu Oda, International Control of Sea Resources (E. D. Brown) $\dot{E}_{\mathrm{ET}}$, The European Conventicn on Human

Gomdon L. WEI, The European Conventicn on Human
Rights: Background, Development and Prospects (Alec Samuels)

Dario Clericetri, $\dot{L}$ Affaire Ambatielos devant la Commission Arbitrale (Paul O'Higgins) . . . . . .

Robert K. Woetzel, The Nuremburg Trials in International Laro. 2nd edition (D. Lasok) . . . . .

Nathan Feinberg, Palestine Under the Mandate and the State of Israel. Problems in International Law (Norman

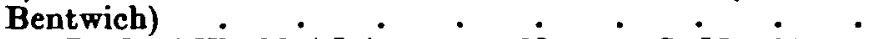

The Year Book of World Afairs, 1963 (Norman S. Marsh)

International Governmental Organisations. Constitutional Docrments. 2nd edition (Norman S. Marsh) . .

Aleert A. Ehrenzweig, A Treatise on the Conflict of Lazos (D. M. Kloss)

Gunter Krsker, Die Ruckurking von Gesetzen. Eine Unter-
suchung zum Anglo-amerikanischen Recht (E. J. Cohn)

Volkert HofPMEYer, Die Getichtswahlklausel in Konnossement. Eine Rechtsvergleichende Strdic (O. C. Giles)

Common Market Law Review. Volume 1, No. 1 (Valentine Korah)

Cutrent Legal Problems, 1963 (Norman S. Marsh) ${ }^{\circ} \cdot$

MARCEL GOTZEN, Vrijheid van beroep en bedrijf \& antechtmatige Mededinging (L. A. Ellwood) . 
G. Oudemang, The Draft European Patent Convention (G. W.

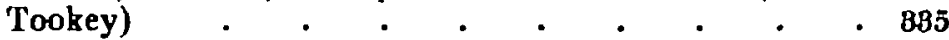

The EEC Reports on Tax Harmonization (E. B. Nortcliffe) . 838

Sroiss Measures against Abuse of Tax Conventions and The Corporate Income Tax in Sroeden (Dennis Thompson) 839

Folke Scmmd, The Lato of Labour Relations in Sroeden (K. W. Wedderburn) . . . . . . .

T. B. SMITH, A Short Commentary on the Laros of Scotland (C. P. Harvey) . • . . . • • . 844

Lond Dennina, Borrouing from Scotland (M. R. Topping) . $\mathbf{8 4 7}$

Guenn G. Morgan, Soviet Administrative Legality: The Role of the Attorney-General's Office (A. K. R. Kiralfy).

J. N. Hazard and Isaac Shapiro, The Soviet Legal System (A. K. R. Kiralfy)

K. GrzYBow SkI. Soviet Legal Institutions (A. K. R. Kiralfy)

W. Warkallo, Odpotviedzialnosc Odszkodozoawcza (Liability for Damage) (D. Lasok)

Law in Eastern Europe. No. 7, Miscellanea, Articles and Teats (Bernard Rudden) . . . . . .

Maxine Boond Virtue, Survey of Metropolitan Courts: Final Report (E. R. Guest) . . . . . . 857

Edward McWhinney, Compatative Federalism (Dennis Thompson) . . . . . .

K. C. WhEARE, Legislatures (Norman S. Marsh) · $\cdot$

Changing Law in Developing Countries. J. N. D. ANDERgon (Editor), (W. Friedmann) - $\cdot$ :

Str Lioner. Brett and IAN McLean, The Criminal Law and Procedure of Lagos, Eastern Nigeria and Western Nigeria (S. S. Richardson) . . . . . .

M. J. Campaeli, Law and Practice of Local Government in Northern Nigeria (H. H. Marshall) . • • . 867

S. N. Chinwuba Obi, The Ibo Law of Property (H. H. Marshall)

Durga DAs Basu, Commentates on the Constitution of India, 4th Edition, Vol. 8 (J. Duncen M. Derrett) .

Donalo E. Smrth, India as a Secular State, and Administration and Economic Development in India (R. Braibanti and J. J. Spengler, editors) (J. Duncan M. Derrett) -

Joseph Mnatrur, Martial Lazo in India, Pakistan and Ceylon

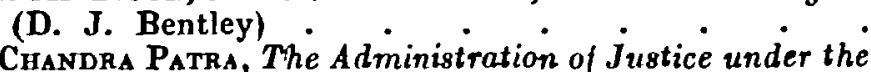
Atul Chandra Patra, The Administration of Justice under the
East India Company in Bengal, Bihar and the Orissa

(L. M. Jopling)
Essays on the Indian Penal Code, S. Govindarajulu (Editor) (Orby H. Mootham) • . • . . . 878

T. H. VAN REENEN, Land, Its Oronership and Occupation in South A frica (M. A. Millner) . . . . . . 880

\section{NOTICES}




\section{International and Comparative Law Quarterly}

VOLUME 18

1064

INDEX 


\section{INDEX OF CONTRIBUTORS OF ARTICLES AND NOTES}

('The titles of articles are shown in cspitals)

Azexamdeowice, Charles Hegat, Inteknational. Law in the Municipal Sphera Accondixo to Augtraliax Declojoms

Agromd, Ja., H. H., 'The Afolo-Japanege Combrecial Treaty of 1963

Amderbox, D. R., Reazhuations to Multilategal Conventiong: A Re-Examination

Athulathaduali, Lalith W., The Laf of Depamation in Cerlon-A StUdy IN THE INTER-ACtION OF EgOLIOH AND ROMANDutch Law

Asear, Issny, The Dispute Between France and Brasll over Lobster Fishing in the Atlantle

Babtholomet, G. W., Recoonition of Polyoamovs Maraiages in America

Brddard, Ralph, The Second Protocol to the European Convention of Human Rights

Bentwich, Nogray, The Leand Systed of I saaed

Borle, Anthony Joly, The Sale or Cortrollima Sharya Amgalcan Law ayd tie Jenkiss Committer.

Batuog, Johy W., The Cage por an Integnationat. Coupt of Criminal Justice axd the Fobmulation or imternational Criminal Law

Browy, Brbnard, The "Ordixary Max" in Provocation: Aralo-Saxor Atritudes and "Unbeagorable NorErolishmes"

Carpesazl, Kenneth, with C. John Colombog, Sir Cecil. Hirati Two Triautes, 11

Cantwrioht, Hilaky, The Law of Ondoationg in England and Gramany: Somp Companative Repixctions in the Lioht oy tile Paopogat.s in "Lair Rerogk Now"

Caxrox, R. W., Judge-Made Law in the Colonies

Cons, E. J., Article 85 of the Rome Treaty-A Matter of Translation 1468

Colomos, C. John, with Kengeth Carpmarl, Sir Cechl Hurst : Two Trigute8, 11

Davis, J. L. R., Compitional Sales ano Chattzl Mortonoeg in the Conplict of Laws

Dex Vecchio, Groporo, The Crigis in International Law and the Law of Sociality

Dearett, J. Duncan M., Jewigh Law in Southern Asia

De Vigscher, Cilariss, Sir Cecil. Huggt: Two T'ributes, I

Do Nascimento e Siliva, G. E., The Vienna Conpehrince on Consuiar RKIATIONB

Drago, Roland, Somi Recent Reporms of the Prench Congeic D'Etat

Drucker, Alfred, A Code of International Trade

Erow Danigls, W. C., The Interaction of Enolish Law with Customary Law in Webt Afaica

Gegs, Karol N., Permasent Sovergiontr over Natubal Resougcrs : AN Anat.rticat, Review op the United Nations Dechatation and itg Genesis 
GovixdazaJ, V. C., Forejgn Arbitral Awards and Foreign Judgments based upon such $A$ wards

Greoo, Rogent W., 'The Unityo Nations asid the Opium Phoblem

1468

Harri, D. J., The European Social Charter

Havahey, Charles J., Law Rejonm in laelani"

Jenninos, R. Y., Recent Developagets in the lNteanational Law Comarission: Its Rreatiox to THE Sougces of INTERational Laiv

Johngon, D. H. N., 'The Care Concegnino the Nortuegn Camegnong

Kahr-Faeund, O., Fifth International Congress for Labour Law and Social Legislation, Septenuber 1963

Kasusmu, A. B., The Principle of Acknowledgment or Recognition of Paternity under Customary Law in Nigeria

KeItH, K. J., State Succession to Treaties in the Commonwealth: Two Replies, I

Kos-Rancewicz-ZubKowski, L., Quebec (Provincial) and Canadian (Federal) Rules on International Procedure (International Judicial Assigtnnce) in Civil and Commercial Matters

Lalive, Jeax-Flavien, Contzacto Between a State or a State Aoency and a Foneigan Company-Theory and Practice: Cifoice of Law in a New Argituation Cage

Lasox, D., The Polish Merchant Shipplng Code .

Lili.ich, Richand B. The Jibispaudexce op the Fogejox Conpensation Commisoror: Eriolale Ciampants

Livagh, ERsst, The Israel Defamation Bill, 1968

Mcausias, J. P. W. B., The Repunilcan Constitution of Tamoanyika

Maxs, F. A., Anglo-American Conflict of International Jurisdiction

Mansu, Norean S., Council of Europe: (2) The European Convention of Human Rights

502

1460

Margihal, H. H., Statute Law Revision in the Commonifealti 1407

Maвshas, H. H., Interpretation of the Constitution of Western Nigeria : $\Lambda$ Privy Council Decision

Manemaxs, H. H., The Judicial Committee of the Privy Council a $A$ Waning Jurlscliction

Morrig, J. H. C., The Wills Act, 1968

Neville Brown, L, Famil, Maintenaxce axd its Exroacebrext in THE UNITED STATt:s

Nroh, P. E., Foreion Status, Public Poljcy and Discretion

O'Cossels, D. P., State Succession to Treaties in the Commonwealth s Two Replies, II

Powles, Sir Guy, The Citimen's Riahts Aaninst the Modern State,

Sabbati, E., EFptcts of Mistakeg in Conteacts: A Study in Comparative Law

Saxena, J. N., India-The Exthadition Act, 1962

Schick, F. B., Phodlems of a Stace Laip in the Unitgo Nationg

Sefrvai, H. M., Certiorarl and Error Apparent on the Face of the Record in Indian Law

Shem idan, L. A., Constitutional Pongeag of Malaysia

Simaionds, K. R., The UN Aegessurests Anvibony Opinion

Siamoxds, K. R., Council of Europe: (1) The Legal Programme of the Council of Europe

Simmords, K. R., The Duration of International Jurisdictional Immunities. (Based on Zosrusch v. Waldock and A nowhor.)

Strojarols, S., A Recent Contribution to the Problem of Torts in the Conflict of Laws 
Surrencr, Erwix C, International Inspection in Pelagic Whaling

666

Szanzy, Stephey, The Duty to Conclude a Contract in East European Law

1470

Thompson, Dennis, The Eubopear Ecomomic Compunity: Irtearal Developmenta Simce the Bazakdowy or the Beitigh Negotiation:

890

Thospsor, Darsis, The Hearings Regulation of the E.E.C. Commission

264

Thosrpsor, Dexsis, Council of Europe: (8) Convention on the Unification of Certain Points of Substantive Law on Patents for Inventlons

684

Uroza, J., Life Irsurasce and the Conflict of Laws

Vay Panhuye, H. F, Iy me Bondeglaxd Between the Act of State Doctrime AND Quegtions of JuRisdictional Imohomities 1198

Veartugini, V. G., Momopolies axt Restrictive Thade Practices is ITALY

vox Laxpauer, Donald, Matrimonial Causes ix Faexch Law

617 


\section{INDEX OF CASES NOTED}

(Names of contributors are inserted in parontheses)

Adegbenro o. Akintola [1968] A.C. 614 (P.C.) . . . . . 280-284

Northern Cameroons Case, I.C.J. Reports, 1968, p. 15 . . . 1148-1192

Sapphire-NIOC Arbitration, 1968 . . . . . . . . . 1002-1021

UN Assessments Advisory Opinion, I.C.J. Reports, 1962, p. 161 . 864-898

Zoemsch o. Waldock and Another [1964] 2 All E.R. 256 . . 1489-1441 


\section{IN.DEX OF BOOK REVIEWS AND BOOKS RECEIVED}

(The page on which the book is reviewed is shown in italics)

Administration and Economic Development in India. Edited by $\mathbf{R}$. Braibants and J. J. Spengler

Annuaire de Leggislation Française et Etrangere. Tome XI, 1962

Annual- Legal Bibliography, Harvard Law School Library. Volume 8, July 1, 1962-June 80, 1963

Annual Survey of South African Law. 1962.

Arazl, Arye. Le Système Electorale Israéllèn

1141

Asian African Legal Consultative Committee. Report of the Fifth Session Held at Rangoon. Jinuary 17-80, $1968 \quad 766$

Asian Comparative Law Review, 1968: Volume I; 1968

Aslaoui, Omar. Les Conclusions et Leurs Modiflcations en Procédure Judlclaire Internationale

Asser, Jan. Maritime Liens and Mortgages in the Conflict of Laws

Attla, Gamal el Din. Les Forces Armées des Nations Unles en Corte et au Moyen-Orient:

Bahramy, Ahmad-Ali. Aspects Internationaux du Problème du Développement Economique et Soclal! Ie Législation Internationale du Travall et son Influence sur le Drolt Iranien

Banerjee, Tapas Kumar. Background to Indian Criminal Law
Basp, Durga Das. Commentary on the Constitution of Indla: 4th Edition, Vol. 8

Basu, Durga Das. Commentary on the Constitution of Indla. 4th edition. Vol. 4

Baumann, Jochim: Das Recht dèr Handelsgesellschaften Im Englischen Rechtskrels

Bekaert, Hermann. Introduction à L'Etude du-Drolt

Berman; Harold J. Justlee in the U.S.S.R. An Interpretation of Soviet Law

Bernini, Giorgio. La Tutela Della Libera Concorrenza e I Monopoll. Vol. I : "Common Law" e Legislasione "Antltrust" Statunitense; Vol. II : Comunita Europee e Leglslasione degli Sthti Membri

Bllyou, De Forest. Alr Law

Blaser, Pierre Michel. Ln Nationalité et la Protection. Juridique Internationale de l'individu.

Boasson,, Dr. C. H. Approaches. to the Study, of International

Buckstlegel, Karl-Heinz. Die Allgemein grundshitze deg Volkerrechts liber Eigentumsentsiehung'

Bouches, L. J. The Régime of: Bays-inı Internatlonal. Law
Boutros-Ghali, Boutros: The -Addis Ababa Charter

Bowett, D. W. The Lnw of International! Institutions

Brett, SIr Lionel and! Ian McLean. Crminal Law. and: Procedure of Lagos; Eastern and Western, Nigeria.

British Yearbook of Internatlonal Law: 1962, Vol. XXXVIII 1806

Brounlie, Jan, International Law and the Use of Force by States 1107 
Cahiers de Bibllographie Juridique. Series A. No. 2, 1968. Publlshed under the auspices of L'Association des Sciences Juridiques

Campbell, Alan. Restrictive Trading Agreenents in the Common Market, Texts-Commentarjes

Campbell, M. J. Law and Practice of Local Government in Northern Nigeria

Canada-United States Treaty Relations. Edited by David R. Deener

The Canadian Yearbook of International Law. Volume 1, 1963

Canizares, Felipe-de Sola. Tratado de Derecho Comercial Comparado. Tomo I, II \& III

Carey, John. Soo Thomas M. Franck.

Carswell, Robert D. Trustce Acts (Northern Ireland). A Handbook on the Trustee Acts (Northern Ireland) 1958 and 1962, and the Trustee Investments Act, 1961

Catalano, Nicola. Mnnuel de Droit des Communautés Européennes

Changing Law in Developing Countries. Edited by J. N. D. Anderson

Cheathem, Elliott Evans. A lawyer When Needed

Chesnes, Guy. L'Etablissement des Etrangers en France et la Communaute Economique Européenne

Clericetti, Dario. L'Affaire Ambatielos devant la Commission Arbitrale

Codding, George A. Jr. The Universel Postal Union. Co-ordinator of the International Mails

Law and Politics in Space. Edited with an Introduction by Maxwell

Cohen
Cole, J. S. R. and W. N. Denison, Tanganglka, The Development of its Laws and Constitution

Colliard, Claud-Albert. Institutions Internationales. 2nd edition

Common Market Law Review. Volume 1, No. 1

Les Consequences d'ordre interne de la Participation de la Belgique aux Organisations Internationales

Contributions Nérlandaises au Sixizme Congrès International de Droit

Comparé. 1962
Coulson, N. J. A history of Islamic Law. Islamic Surveys (2)

Current Legal Problems, 1968

Currie, Brainerd. Selected Essays on the Conflict of Laws

1141

Current Law and Social Problems. Volume III. Edited by E. E. Palmer 760

Contributions to Synthetic Jurisprudence, Edited by M. J. Sethna 750

Dahm, Georg. Volkerrecht Three volumes

Daniele, W. C. Ekow. The Common Law in West Africa

Danish and Norwegian Law

Davis, A. G. The Law Relating to Commercial Letters of Credit Third edition

Davis, Morris. Iceland Extends its Fisheries Limits. A Polltical

Dean, W. H. Evidence in Nigerian Criminal Law

"De Becker" Case. Publications of the European Court of Human Rights. Series B: Pleadings, Oral Arguments, Documents 1962

Decisions of the Arbitral Commission on Property, Rights and Interests in Germany. Volume $V$ (Nos. 100-114)

Decolonisation et Independance du Rwanda et du Burundi. Chronlque de Politique Etrangère. Vol. XVI, 46

Degan, V. D. Linterprétation des accords en droit international

Dekkers, René. Introduction au droit de l'Union sovietique et des Republiques populaires

Denison, W. N., see J. S. R. Cole. 
Denning, Lord. Borrowing from Scotland

Derrett, J. Duncan M. Introduction to Modern Hindu Law

de Smith, S. A. The New Commonwealth and its Constitutions

Les Difficultes financières des Nations Unies et les obligations des Etats meinbres. Chronique de Politique Etrangère. Volume XVI, No. 1-2, 1963

Disarmament. Background Papers and Proceedings of the Fourth Hammarskjbld Forum

Dubbinck, C. W., see J. Kosters.

Dubisson, Michel. La Cour Internationale de Justice 1115

The EEC Reports on Tax Harmonisation

Ebb, Lawrence F, Regulation and Protection of International Business; Cases, Comments and Materials

Ehrenzweig, Albert A. Sueo Ikehara and Norman Jensen. American-

Japanese Private International Law
Ehrenzweig, Albert A. A Treatise on the Conflict of Laws

Ellert, Robert B. NATO "Falr Trial" Safeguards

Erdmenger, Jurgen. Die Anwendung des EWG Vertrages auf Seeschiffahrt und Leiftfahrt

Essays on Jurisprudence from the Columbia Law Review

Essays on the Indian Pennl Code. S. Govindarajulu (Editor)

Etude Comparative du Droit de la Cooperation Agricole en Europe 1141

Etudes de Droit Contemporain: rapports francais au Ve Congrés de Drolt compare, Bruxelles, 1988

Excerpta Criminologica Volume 8, No. \$ July/Aug. 1968

Exposicion de Motivos y Proyecto de Ley de Normas de Derecho International Privado

Pabrega P., Jorge. Jurisprudencia de la Corte Suprema. Sobre Procedlmiento Civil 1940-1968. Extractada y Concordada por

Fabrega P., Jorge. La Finalidad de la Casacion

Fatouros, A. $\Lambda$. Government Guarantees to Foreigm Investors

Fawcett, J. E. S., The British Commonwealth in International Law

Feinberg, Nathan. Palestine Under the Mandate and the State of Israel. Problems in International Law

Foulkes, David. Introduction to Administrative Law

Foyer, Jacques. Filiation Illégitime et Changement de la Lol Applicable

Franck, Thomas M. and John Carey, The Role of the United Nations in the Congo

Friedmann, Wolfgang. The Clanging Structure of International Law

Fyree, Asaf A. A. Outlines of Muhammadan Law. Brd. edition

Garaicoa, Theodoro Alvarado. Los Princlpios Internacionales de No Intervencion y Autodeterminacion

Gehrke, Ulrich and Gustar Kuhn. Die Grenzen des Irak. Historische und rechtliche Aspekte des irakischen Anspruchs auf Kuwait und des irakisch-persischen Streites um den Schatt al-A rab

Giles, F. T. The Magistrates' Courts

Gledhill, Alan. The Penal Codes of Northern Nigeria and the Sudan

Goldfard, Ronald, L. The Contempt Power

Goldschmidt, Roberto. La Letra de Cambio y el Cheque en la Legislacion Venesolana

Goldstajni, Aleksandar. Pravo Medunarodne Kupoprodaje (The Law of International Sales of Goods)

Goldstein, E. Ernest. American Enterprise and Scandinavian Antltrust Law 
Gotzen, Marcel. Vrijheid van beroep en bedrijt \& onrechtmatige Mededinging

Grant, J. A. C. El Control Jurisdiccional de la Constitucionalidad de Las Leyes

Graue, Eugen Dietrich. Die mangelfrle Lleferung beim Kauf beweglicher Sachen

Grisoll, Angelo. Contributo Alla Ricerca del Principli Generall comuni al Diritti degli Stati della Comunita Europea in Materia di Responsabilita Extracontrattuale, Vols. I \& II 758, 11E7

Griswold, Erwin N. Two Branches of the Same Stream

Gross, Bernard. La Notion d'Obligation de Garantie dans le Droit des Contrats

Grzybowskl, K. Soviet Legal Institutions

1148

Gupte, S. V. Hindu Lnw of Succession

Hagel, Karl. Der EInfache Diebstahl in Englischen und Deutschen

Recht. Elne rechtsvergleichende Studie
Hahlo, H. L. The South African Law of Husband and Wife.

$\$ 62$

751 and edition

Hall, Jerome. Comparntive Law and Social Theory

Hambro, Edvard. The Case Law of the International Court. Volume

III. Individual and Dissenting Opinions 1947-1958 757, 1117

Hardy, M. J. L. Blood Feuds and the payment of Blood Money in the Middle East

Hay, Peter, seo Eric Stein.

Haxard, J. N. and Isaac Shapiro. The Soviet Legal System

Heuston, R. F. V. Essays in Constitutional Law. 2nd edition 1523

Hiemstra, V. G. Engels-Afrikaanse Regswoordeboek

1157

Higgins, Rosalyn. The Development of International Law through the Political Organs of the United Nations

398, 1501

Hinsley, F. H. Pon'er and the Pursuit of .Pence

Houben, P. H. J. M. Les Conseils de Ministres des Communautés Européennes

Hoffmeyer, Volkert. Die Gerichtswalilklausel in Konnossement. Eine Rechtsvergleichende Studie

lkehara, Sueo. Soo Alluert A. Ehrenxweig.

Howard, Colin. See Norval Morris.

The Indinn Year Book of International Affotrs 1968

Innes, L. A. Rose. Judicial Review of Administrative Tribunals in South Africa

The Inter-American Security System and the Cuban Crisis. Background papers and proceedings of the third Hammarskjold Forum

International Bar Association. Ninth Conference. Edinburgh, July $16-20,1962$

International Court of Justice Yearbook 1962-1968 2nd. edition

International Law Associntion. Report of the Fiftieth Conference, Brussels, 1962

International Law in a Changing .World

International Review of Criminal Pollcy. No. 20. December 1962

Jacob-Steinorth, Dr. Karl. Der zwelgleisige Vertrieb von Markenwaren im deutschen und amerikanischen Recht

Jalpur Law Journal. Vol. B; All India Jurisprudence Seminar Issue 1198 Jenks, C. W. Law, Freedom and Welfare

Jensen, Norman. Seo Albert A. Ehrenzweig. 
The Journal of Modern African Studies $7 \& 8$

Justis im Dritten Reich. Eine Dokumentation. Edited by Ilse Staff 1142

Karminski, Sir Seymour. Some Aspects of the Development of English Personal Law in the Last Century

Kisker, Gunter. Die Rulckwirking von Gesetzen. Elne Untersuchung zum Anglo-amerikanischen Recht

Kosters, J. and C. W. Dubbinck. Algemeen deel van het Nederlands Internationaal Privatrecht (General Part of Netherlands Private International Law)

Kots, Hein. Trust and Treuhand

Kritikal tanulmányok a modern polgári jogelméletrol

Kruger, Herbert. Allgemeine Stantsletire

Kruse, Fr. Vinding. A Nordic Draft Code

The Supreme Court Review. 1968. Edited by Philip B. Kurland

Staatsburger und Stantsgewalt, Verwaltungsrecht und Verwaltungsgerichtobarkeit in Geschlchte und Gegenwart. Jubiliunsschrift Herausgegetien von Helmut $R$. Kuls und Prof. Dr. Richard Naumann. 2 volumes

Lador-Lederer, J. J. International Non-Governmental Organisations and Economic Entitles. A Study in Autonomous Organisation and Ius Gentiun

1141

Lapenna, Ivo. State and Law: Soviet and Jugaslar Theory

Langen, Eugen. .Studien zum Internationalen Wirtschaftsrecht

Langrod, Georges. The International Clvil Service

Larson, 'Arthur, seo John B. Whitton.

Lasswell, Harold D., soe Myres S. McDougall.

Law In Eastern Europe. No. 7. Miscellanea, Articles and Texts

Law In Japan. A. T. 'von Metren (Editor)

"Lawless" Case (Affalre "Lawless"). Publications of the European Court of Human Rights. Series B: Pleadings, Oral Arguments, Documents 1960-1961

The Law of Sedition in India

Legal Advisers \& Foreign Affalrs. Edited by H. C. Merillat

Legal Essays. A tribute to Frede Cestberg on the occasion of his 70th Birthday. 4th July, 1968

Legal Problems in International Trade \& Investment. Edited by Craw ford Shaw

The Legal Status Privileges and Immunities of the Specialised Agencies of the United Nations and Certain Other International Organisations

Le Gall, Jean-Pierre. LObligation de Garantie dans le Lourge de Choses

Levitsky, Serge $\cdot$. Introduction to Sovlet Copyright Law

Lumb, R. D. The Maritime Boundaries of Queengland and New South Wa'les

Lyon, Peter. Neutrallsm

McLean, Ian. Bee Sir Llonel Brett.

MeDougal, Myres S., Harold D. Lasswell, and Ivan A. Vlasic, Law and Public Order in Space

MacDowell, Douglas M. Athenian Homicide Law In the Age of the Orators

McWhinney, Edward. Comparative Federalism

Marthaler, Maurice. Le Droit de visite parents sépares de leurs enfants en Sulsse, en France et en.Allemagne

Merchant, G. A. Offences against Property

Mezbfy, Ladislaus. Der Strafkodex der Ungarischen Volksrepublik

Milner, T. B. (Editor). Cases and Materials on Contracts 
Milner, T. B. (Editor). Community Planning. A Case book on Law and Administration

Minattur, Joseph. Martial Law in India, Pakistan and Ceylon

Mora, Manuel R. Garcia. International Responsibility for Hoṣtile Acts of Private Persons against Foreign States

Morgan, Glenn G. Soviet Administrative Legality, the Role of the Attorney-General's Office

Morris, Norval and Colin Howard. Studies in Criminal Law 758, 1511

Mulla, Sir D. F. and E. M. Pratt, The Indian Stamp Act 7

Nagel, Dr. Heinrich. Auf dem wege zu einem europalschen Prozessrecht

Obi, S. N. Chinwuba. The Ibo Law of Property

Oda, Shigeru. International Control of Sea Resources

O'Dowd, A. P. The Law of Evidence in South Africa

Oudemans, G. The Draft European Patent Convention

Park, A. E. W. The Sources of Nigerian Law

Patra, Atul Chandra. The Administration of Juatice under the East

\section{Indla Company in Bengal, Bihar and the Orissa}

Polach, Jaroslav G. Euratom. Its Background, Issues and Economic

Implications
Pratt, E. M. see Sir D. F. Mulla.

Predier, Alberto. Pianificaxione e constituxione

Preiswerk, Roy. La Protection des Investissements Privés dans les traités Bllateraux

Pusylewitsch, Teresa. Strafgesetzbuch der Russischen Sozealischen Föderativen Sowjet-Republik rom 27 Oktober 1960 in der Fassung vom $6 \mathrm{Maj} 1968$

Qadri, Anmar Ahmad. Islamic Jurisprudence in the Modern World

Quelques Aspects Techniques de la Reception des Drolts Occidentaux (Extrait de la Rerue juridique et économlque de la Faculte du Droit de Saigon)

Ramundo, Bernard A., with the assistance of Armins Rusls. The Socialist Theory of International Law 1140,1504

Recht im Dienste der Menschenwurde. Festschrift fur Herbert Kraus 1141

Richardson, S. S. and T. H. Williams. The Criminal Procedure Code of Northern Nigeria

Rigaux, François. Le Statut de la Représentation. Etude de Drolt

International Privé Comparét 791

Robertson, A. H. Human Rights in Europe 756, 1110

The Role of the United Nations in the Congo. Background Papers and Proceedings of the Second Hammarskjold Forum

Roundtable of Western Hemisphere International Law Scholara San Jose, Costa Rica, March B1-April 6, 1968. Final Report

Schechter, Alan H. Interpretation of Ambiguous Documents by Inter-

Schmeiser, D. A. Civil Liberties in Canada

Schmidt, Folke. The Law of Labour Relations in Sweden

Schwarts, Iro E. Deutsches Internatlonales Kartell recht

Schwarzenberger, Georg. The Misery and Grandewr of International Law

Schwarzenberger, Georg. Power Politics: A Study of World Society.

Brd Edition
Schweizerisches Jahrbuch für Internationales Recht (Annuaire Sulsse

de droit International) Vol. XIX, 1962
Selected Judgments of the Supreme Court of Israe]. Vols. I II. Edited by the late David E. Goltein

Selvig, Erling. Unit Limitation of Carrier's Liabllity 
Seyersted, Finn. Settlement of Internal Disputes of Intergovernmental Organisations by Internal and External Courts

Seyersted, Finn. Objective International Personality of Inter-Governmental Organisations. Do their Capacities really depend on their Constitutions?

Simpkins, Edgar, soo Roland . Wraith.

Shapiro, Isaac, soo J. N. Hazard.

Singh, Nagendra. International Conventions of Merchant Shipping. British Shipping Laws No. 8

Smith, Carsten. The Relation Between Proceedings and Premises
Smith, Donald E. India as a. Secular State

Smith, T. B. A short Commentary on the Laws of Scotland

Soonavala, R. K. A Treatise of Law Relating to Bribery and Corruption

Staatsverträge uber Rechtshilfe und Vollstreckung sowle uber andere Materien des xwischenstaatlichen Rechtsverkehrs in Zivilrechtsachen. Edited and annotated by V. Hoyer a R. Loewe

Stambuck, George. American Mllitary Forces Abroad, Thelr Impact upon the Western State System

Starace, Vicenzo. La Rappresentanza nel Diritto Internasionale Privato

Starke, J. G. An Introduction to International Law

Stein, Eric and Peter Hay (Editors). Cases and Materials on the Law and Institutions of the Atlantic Area

Strohl, Mitchell P. The International Law of Bays.

Studies en Voordrachten. 1968, I. Faculteit der Rechtsgeleerdheld, Vrije Universiteit te Brussel

Summaries reprinted from Bohemia Jahrbuch des Collegium Carollnum Band 8. 1962

Swiss Measures against Abuse of Tax Conventions and The Corporate Income Tax in Sweden

Szaszy, Istvan. Private International Law in the European People's Democracies

Sxladits, Charles. A Bibllography on Foreign and Comparative Law. Books and Articles in English. Supplement 1960-1961

Tedesch, Guido. Studies in Israel Law

Teece, Richard Clive. The Law and Conduct of the Legal Profession in New South Wales. 2nd edition

Thanh, NBo Bá. La Sociedad Anónima Familiar Ante la Ley Espanola de 1951

Thomas, Anna Van Wynen and A. J. Thomas, jr. The Organlzation of American Strites

Tope, T. K. The Constitution of India

Tope, T. K. The Supreme Court on Ractal Discrimination. Edited by Joseph Tussman

Tope, T. K. Das Ungarische Zivilgegetzbuch in funf studien. Edited by F. Madl

Van Der Meersch, W. J. Ganshof. Fin de la Souveralneté Belge au Congo

van Reenen, T. H. Land, Its Ownership and Occupation in South Africa

Vicente, D. Luciano Perena. La Tesis de la Coexistencia Pacifica en los Teologos Clasicos Espanteles

Virtue, Maxine Boord. Survey of Metropolitan Courts: Final Report

Münch Dr. Ingo. Das Völkerrechtliche Dellkt in Der Modernen Entwicklung der Volkerrechtsgemeinschaft

Die Volkerrechtliche Lage Kaschmirs. Vorgelegt von Rudolf Gredger

Vouillos, Dr. Benoit. Le Role du Juge Civil a l'Egard du Droit Etranger 
Vlasic, Ivan A. Soo Myres S. McDougal.

Villela, Joao Baptista. Da Compensabilidade no Concurso Falenclal

Waer, David Kent Common Market Antitrust. A Guide to the Law, Procedure and Literature

Warkallo, w. Odpowiedrialnosé Odszkodowawcza (Lability for Damage)

Watera, Maurice. The Ad Hoc Diplomat

Weil, Gordon L. The European Convention on Human Rights : Background, Development and Prospects

Werner, Auguste-Raynald. Traité de Droit Maritime général

Die Waremeichlizens, Edited by Friedrich-Karl Beier, Erwin Deutsch and Wolfgang Fikentscher

Wheare, K. C. Legtslatures

Whitton, John B. and Arthur Larson. Propaganda. Towards Disarmament in the War of Worlds

Williams, T. H., see S. S. Richardson.

Woetsel, Robert $\mathrm{K}$. The Nuremburg Trials in International Law. 2nd edition

Wralth, Roland and Edgar Simpkins. Corruption in Developing Countries

Yearbook of the European Convention on Human Rights, Vol. 6,19621140

The Year Book of World Affairs, 1968 


\section{SUBJECT INDEX OF ARTICLES, NOTES AND DECISIONS}

(The titles of articles are shown in capitals.)

Act of State Doctrine

IN THE BordegLaxd heTwEeN the Act of State Docteine AND Quebtions of JuRiadicTIONAL IMMUNITIEs 1188-1218

Diplomatic and Consular Immunities $1208-1209$

State Immunity and $1195-1208$ Administrative Law

Sos France, Consell D'Etat

Agency

S6e Germany, United KIngdom

Anolo-Japanese Comarecial Texaty op 1968

925-968

Analysis 992-9.89

Establishment provisions 989-946

Protection of Private Property from publlc taking

946-952

Text

954-968

Arbitration

Choice of law

methods

Sapphire-NIOC Arbitration, 1963

Arbitra-

transnational law 1006-1009

Sos also International Contracts

Foreign Arbitral $\Lambda$ wards 1466-1470

Sapphire-NIOC Arbitration, 1968

Judgment, texts, extracts

See also International Contracts

Australia

International lew, application of

ImTterational LAN TI THE Municipal Sphene accondivo to Austratian Decrsion:

International customary law in

$79-86$

Statute law replsion

Treaty law

$1410-1420$

86-92

\section{Braxil}

Lobster dispute with Prance

British Commonwealth Soo Commonwealth

Cameroons

Bee Northern Cameroons

Canada

Rules on International. Pro cedure (International Judi-

cial Assistance)

270-279

Statute law revision

1416

Certiorart

India

1491-1500

Ceylon

English law, treatment of 1872-1880

Defamation

The Law or Deramatios

Ix Cerzox-A Study IN

THE IMTER-Action OP

ENotisy aND Romak-

Dutch Lat 1868-1406

Animus infuriandi $1382-1887$,

1388-1399

clessiffcation of $\quad 1880-1881$

defences 1888-1403

mallce 1887

publication 1881-1382

truth as a defence 1400-1403

Roman-Dutch law, treatment of

$1872-1880$

Chattel Mortgages

Conditiogal Sales ayd Chattel Mogtonozs in the ConFuICT or LAW:

68-77

Choice of Law

Soo International Contracts

Colonial law

Judges influence on

$284-288$

Commonwealth

Dependent Territories

Statute law revision 1409-1414

State Succession to Treaties

Statuts Lat Revibiox IM 1441-14603 THE Coxoroxwealth 1407-1498

See also undor Statute Law Revision 
Company Law

The Sale of Controllino

Shares: arealcas Lat AND THE JENK1NB CoMmiTTEE

Sıo also Germany, United Kingdom

Conditional Sales

Conpitional Saleg and ChatTeL Mortonage ix t7is ConFLICT OP LAw

Conflict of Laws

Torts and $691-697$

Consular Law

Codiflcation

1215-1218

Vienna Comreremce on Conaular Relation:

1214-1254 organisation 1218-1220

Vienna Convention on Consular Relations

1220-1229 text

1230-1264

Contracts

Eastern Europe duty to conclude

1470-1482

Germany 1829-1843

Mistake

EfFects of Mistake ix Compracte: A Study in Comparative Law 708-829

Damages

812-819

Nullity

$798-812$

Rectification

810-827

Sec also International Contracts

Council of Europe

Convention on the Unlfication of certain points of substantivo Law on Patents for Inventions

European Convention on Human Rights, publications concerning

$680-688$

Legal Programme

$675-680$

See also European Social Charter

Criminal Law

Soo International Criminal Law

Czechoslovakia

Code of International Trade

$671-675$

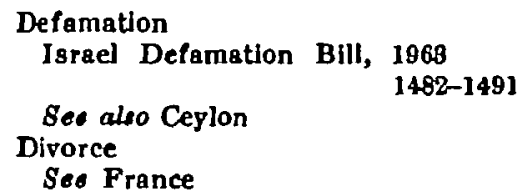

Eastern Europe

contracts

duty to conclude 1470-1462

European Economic Community

The Eugopeas Economic

Comomitit: Integnal

Developments BINCE THE

Breakdowy of the British

Neaotiation:

890-868

Commission:

Hearings Regulation 264-270

Competition, Rules of $845-860$

British Negotiations, breakdown of

892-886

Counci]

recent decisions $\quad 837-841$

Court of Justice 841-845

Harmonisation of Laws

recent developments $\quad 860-864$

Second stage $\quad 830-832$

Treaty

Article 85, translation $1468-1470$

European Commission of Human Rights

jurisdictional immunities of members and employees

148B-1441

European Convention of Human Rights

Council of Europe, publications of concerning $\quad 680-683$

Second Protocol, $1969 \quad 266-259$

European Social Charter 1076-1087

Exhaustion of National Jurisdiction

United Nations Declaration on permanent sovereignty over natural resources

$420-489$

684 Expropriation

Anglo-Japanese Commercial Treaty of 1968

946-952

United Nations declaration on permanent sovereignty compensation for Nationalisation, Expropriation and Requisitioning

$420-429$

Extradition

India-The Exthadition ACT, 1062

116-138

Family Courts

England

$180-182$

United States

177-179

Foreign Compensation Commission

THE JURISPRUDENCE OF THE

Foreiar Compensation

Commigaton: Eltarale

Ceaimants

899-924 
Foreign Compensation Commission -cont.

Eligible Claimante Corporations 908-911 Individuals as claimants Partnerships Stock holders

$900-907$

907-908

911-921

Trustees

922-928

Foreign Judgments, enforcement and Recognition

France

Forelgn Arbitral Awards based on

81-38

$1465-1470$

France

Conseil D'Etat

SOME REcent REFonMs of the Faench Corseil D'Etat 1282-1299

Execution of Judgments 1297-1299

Functions of Members 1290-1291 Internal Structure

1291-1207

Status of Members

$1286-1290$

Divorce

$11-13,28-26$

Domestic Law

10-19

Foreign Judgments

31-88

Judicial Separation

18,26

Jurlsdiction

22-81

Maintenance

Matribonial $17-18,29-80$ French Law Caugra IN Nullity

15-17, 27-29

Lobster dispute with Brasil

Status, law of

1468-1469 19-22

Genocide Convention

Reservations to

$467-468$

Germany,

Law of Obligatioms in Exocard ard Germany: Some Compakative Refiections in the Lioht of the Pzopoyals is Law Refony Now 1816-1848

Agency 1346-1847

Bona fide person, protection of 1849-1848

Company, directors liability

Contract

Treu und Glauben

1847-1348

$1329-1348$

$1830-1839$

Negligence

$1817-1824$

Tort

1317-1829

Tortious Liability
Human Rights

Soe European Convention of Human Rights

Husst, Sir Crcil

Immunities

8os State Immunity, International Jurisdictional InImunities

India

Certiorari and Error on the Face of the Record 1491-1500

Extradition Ixdi-The Extraditios AcT, $1862 \quad 116-188$

Forelgn Judgments, enforcement

$1465-1470$

Jewish law In,

288-801

Statute law revision $\quad 1421$

Insurance

Life Irguanace and the CorFuICT OP LAW: 482-601

Life Insurance

Contractual nature $\quad$ 484-492

forum, cholce of 498- 501

Property, as

$492-498$

International Contracts

Contractg Between a State or a State Aoemct axd A Ponerox Compant: Theont aro Panctice; Cholce or Law in a New Agbitration Cabe

See also Arbitration, Choice of law

Nature of

International Court of Justice

The Case Corcermino the Northeray Cascenooss

1148-1192

Bes also Northern Cameroons Case

ThB UN Assegsmerts ADviBOAY OPINION 854-898

Soo also UN Assessments Advisory Opinion

South West Africa Case 1161-1168

Spender, Sir Percy C. $\quad 665$

Wellington Koo, Dr. V. K. $\quad \mathbf{6 6 \theta}$

International Criminal Court

The Cabe for an ImtenanaToNal Coutr of Cemminat Justice AND THE Fondulation of Inteaxational CarMINAL Lat 1256-1281 characteristics of 1278-1277 International criminals, trial of $1260-1280$ 
$\begin{array}{cr}\text { International Criminal Court--eont. } \\ \text { means of creation } \\ \text { need for } & 1277-1280 \\ 1266-1278\end{array}$

International Criminal Law 1200-1266

The Case ror an Internatomal Cougt of Caiminal Justice aNd the Fonmulation of Imtennational CaiMisal Law 1255-1281

International Criminals trial by International Tribunal 1260-1280

trial by Municipal Courts

1266-1260

International Jurisdiction

Anglo-American conflict $1460-1465$

International Jurisdictional

Immunities

Duration of

$1498-1441$

International Law

Law of Sociallity and 260-269

Municipal sphore, in

InTEAYATIONAT LAW IN THE Municipal Sphene AcCOBdjyo to Augthalian Decralon:

Sources 386-897

International Law Commission

Recent Developmenta in tie Internatjoxal Lat CokMission: Its Relation to THE Sotrces of IXTrRDATIONAL LAw 886-897

Reservations to Multilateral Conventions $\quad 468-476$ draft articles, text $\quad 479-481$

International Trade

Code of Crechoslovak

671-675 Hague Draft 671-675

Sos also Anglo-Japanese Commerclal Treaty of 1968

Ireland

Law Repork ix Jaemaxd 1800-1816 Bibliography

Statute Lew revision 1806-1808

Israel

The Leoal Syoter of Igraet

286-8.65

Defamation Bill, 1968. 1482-1491

Italy

Moropolies and Restaictivf Trade Paacticeg. in Italy

history

$617-642$

present law
Japan

Soo Anglo-Japanese Commercial Treaty of 1968:

Jewish Law

Southern Asia, in

289-801

Labour Law

Fifth International Congress for Labour Law and Social Legislation, Sept. 1868 801-808

Law Reform

See Germany, Ireland, Statute Law Revision, United Kingdom

Lobster Fishing

dispute between Prance and Brazil

1468-1469

Maintenance

Fayily Maintenarce axd its Exponcement IN THE United States $189-189$

Malaya, Federation of Constitution judicia] decisions $\quad 1858-1369$

Malaysia

Cometitutional Problems or Mazapaia 1849-1867

- Constlution Background 1349-1358 Bibliography 1866-1867 citizenshlp 1862-1366 structure 1869-1868

Marriage

Seo Polygamous Marriages

Matrimonial Causes

France

Monopolies

Beo Italy

Multilateral Conventions

Regenvatioge to Multilatebal Conventions $\quad 460-481$

Definition 460-464

International Law Commission $\quad 463-476$

International Law Commission's draft articles, text

$479-481$

Genocide Convention $\quad 467-468$

History $464-467$

Nationalisation

See Expropriation

National Jurisdiction

Boo Exheustion of Nationa]. Jurisdiction 
Natural Resources

Sovereignty over

New Zealand

Ombudsman

The Citiser's Rights

Against THE Modery

STATT, AND ITS REsponsiBILITIES TO H1M 761-797

Provocation 220-229

Reasonable man, the 220-223

Statute Law Revision 1420-1421

Nigeria

Paternity, Recognition of 1099-1104

Western

Constitution of

Northery Camroons, the Case

Coxcensiso

280-284

Arguments of the Parties 1166-1178

Background

1158-1166

Judgment of: the Court. 1179-1179

Soparate and Dissenting Opinions 1179-1191

South West Africa. Case and

1151-1168

Ombudsman

New Zealand

The Citiega's Right:

Aanjyst THE MODEEY

STATE, ayd ITS ReaponoyHILTIES TO HIM 761-797

Oplum

THE UNITED Nations AND the Opiuse Phoglem

96-116

Parliamentary Commissioners

Sos Ombudsman

Patents

Convention on the Unification of Certain points of Substantive Law on Patents for Inventions

684

Paternity

Sec Nigeria

Poland

Merchant Shipping Code 1087-1098

Polygamous Marriages

United States

Rzcooxitioy of Polyanaroul Marbinaze ix Aaremica 1022-1075

American-Indian. Marriages 1038-1068

"Foreign" Marrlages 1068-1075

Mormon Marriages. 1022-1063

Private International Law

See Subject headings
Privy Council, Judichal. Committee of

Jurisdiction, waning

Procedure, International

Canada and Quebec

Provocation, defence of

Tue "Obdivart Max" in

Provocation: Axalo-

Sayou Attitudes amd "Un-

REABONABLE Noy-EnoLIaH-

MEN"

2003-285

Public Policy

Forejax Statua, Public Polucr and Discaetion 89-62

Quebec

Rules on International Procedure (International Judicial Assistanco)

$270-279$

Reasonable Man, the

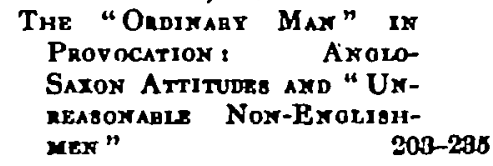

Restrictive Trade Practices

Mosopoliza AND Restaictive Trade Practiceg in Italy

Boe also Italy

Requisitioning

Soe Expropriation

Roman-Dutch Law

Sao Ceylon

Sea, law of

Sos also Lobster Flshing, Whaling

Shipplng

Anglo-American Conflict of International Jurisdlction

Soo also Poland'

$1460-1466$

South West Africa Case 1151-1168

Sovereignty

Pemmaxent Sovramiont Orbi

Natural Rescurces. B98-149

Space Law

Problemg- or a. Space Iant in THE UXited NATIONa 969-986

Spender, Sir Percy C.

665

State. Immunity

Act of State Doctrine and

1195-1200 


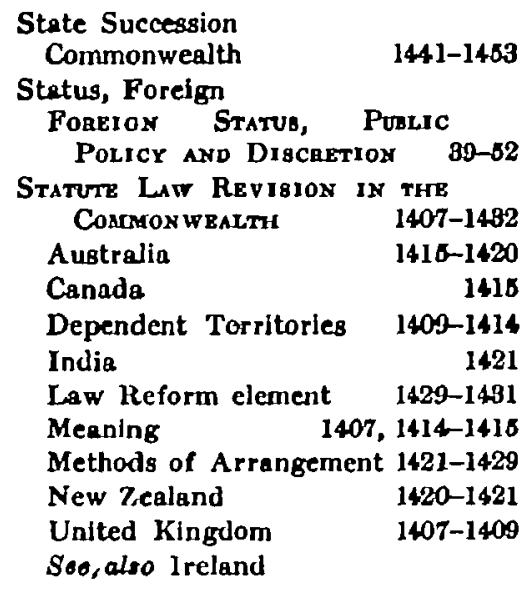

Tanganyika

The Republican Constitution

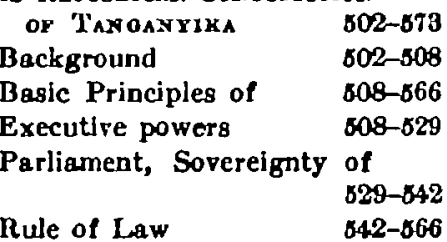

Torts

Conflict of Laws and 691-697

Soo also Germany, United

Trade Kingdoin

Soo International Trade

Treaties, law of

Australia

$86-92$

Multilateral Conventions

Regenvatioys to MuLtitateral Corvextions 460-481

Soo also Multlateral Conventions

See also Anglo-Japanese Commercial Treaty of 1968, State Succession to Treaties

United Kingdom

Company Law

The Sale of Controllino

Sharea a arericas Law AND THE JENKINa CaMMITTEE

186-202

Jenkins Committee Report

190-202

Family Courts

180-182
United Kingdom-cont.

Law Reform

The Law op OnLioatrons in Emoland and Germant: Some Comparative RePLections IN THE Lioht of the Proposals IN LaH Refors Now

1816-1348

Agency 1846-1347

Contract 1329-1343

limited companies, directors liability 1847-1348

Negligence 1817-1824

Tort 1817-1829

Tortious Llability 1324-1829

Provocation 202-236

Reasonable Man, the 203-283

Statute law revision 1407-1409

Sod also Anglo-Japanese Commercial T'reaty of 1963

United Nations

Assessments Case

See United Nations Assessments Advisory Opinion

Budgetary Arrangements 855-857

Commission on Narcotic Drugs 96-115

Congo Operation, assessments concerning $807-861$

Declaration on permanent soverelgnty over natural resources

Permaneat Soveaziontr: oveb Natubal Resoubes $308-49$

Aims $\quad 406-408$

Compensation for Nationallsation, etc. $\quad 420-429$ Legal aspects $\quad 408-419$ observance of agreements

Resort to or exhaustion of $489-448$ National Jurlsdiction $429-439$

General Assembly

Budget Estimates, $1964 \quad 897$

resolutions on finance, texts 892-897

UNEF Appropriation for 1964, text

$897-898$

Opium and

96-115

Space Law

Pnoblems of a Space Law in THE UNited Natioxs 969-988

Declarations on legal principles governing activities in outer space, text, 983-984 


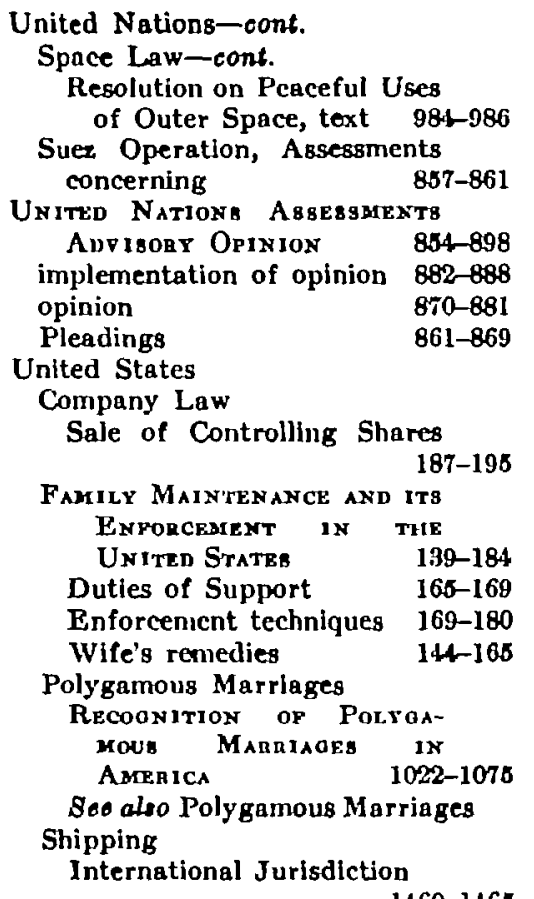

Viexxa Confraexce or Consuinh Relution: 1214-1259

Vienna Convention on Consular Relations text

Seo also Consular law

$1280-1204$

Wellington Koo, Dr. U. K. $\quad 666$ West Africa

The Intraction op EnoLish

LAW WITH Customanx

LaW in Wegt Aprica 674-616 contract 598-697

English Statutes 615-616

intention of the parties $891-898$

Jurisdiction of Courts 674-689

land transactions $\quad 599-601$

Marriage 601-609

parties $\quad 589-591$

Succession and Administra-

tion 610-614

Whaling

International Inspection in Wills

Pelagic Whaling 666-671

Wills Act, 1968, the 684-691 